\title{
Patterns and predictors of current cigarette smoking in women and men of reproductive age-Ecuador, El Salvador, Guatemala, and Honduras
}

\author{
Van T. Tong, ${ }^{1}$ Reina M. Turcios-Ruiz, ${ }^{1}$ Patricia M. Dietz, ${ }^{1}$ \\ and Lucinda J. England ${ }^{1}$
}

Suggested citation

Tong VT, Turcios-Ruiz RM, Dietz PM, England LJ. Patterns and predictors of current cigarette smoking in women and men of reproductive age-Ecuador, El Salvador, Guatemala, and Honduras. Rev Panam Salud Publica. 2011;30(3):240-7.

ABSTRACT Objective. To estimate smoking prevalence by gender, describe patterns of cigarette use, and identify predictors of current smoking in reproductive-age adults in four Latin American countries.

Methods. Self-reported smoking was examined using data from Reproductive Health Surveys of women aged 15-49 years in Ecuador (2004), El Salvador (2002-2003), Guatemala (2002), and Honduras (2001), and of men aged 15-59 years in El Salvador, Guatemala, and Honduras for the same years. Current smoking was assessed by demographic characteristics, and independent associations were examined using logistic regression. Data were weighted to be nationally representative of households with reproductive-age women and men.

Results. Current smoking prevalence ranged from $2.6 \%$ (Guatemala) to $13.1 \%$ (Ecuador) for women and from 23.1\% (Guatemala) to $34.9 \%$ (El Salvador) for men. In Ecuador, $67.6 \%$ of female smokers were non-daily users; in other countries, daily use was more prevalent than non-daily use for both men and women. In daily users, the median number of cigarettes smoked per day ranged from 1.9 (Ecuador, Honduras) to 2.3 (Guatemala) for women and from 2.1 (Guatemala) to 3.6 (Honduras) for men. In bivariate analysis, smoking prevalence in all countries was highest in women who lived in urban areas, were previously married, and/or had high socioeconomic status. Risk factors for smoking varied by country and gender.

Conclusions. National tobacco control programs in these countries should aggressively target high-risk populations (reproductive-age men) and maintain low prevalence in low-risk populations (reproductive-age women). More research is needed to understand addiction patterns in non-daily smokers.

Key words Smoking; women; men; sexual and reproductive health; pregnancy; Ecuador; El Salvador; Guatemala; Honduras.

Worldwide, tobacco use contributes to the deaths of 5 million people each year

\footnotetext{
1 Division of Reproductive Health, National Center for Chronic Disease Prevention and Health Promotion, Centers for Disease Control and Prevention, Atlanta, Georgia, United States of America. Send correspondence to: Van T. Tong, vtong@cdc.gov
}

and is an important risk factor for six of the eight leading causes of death $(1,2)$. Smoking harms nearly every organ of the body; contributes to many disease processes, including cardiovascular disease, cancers, and chronic obstructive pulmonary disease; and reduces overall life expectancy in men and women (3). Female smokers of reproductive age are at increased risk for multiple adverse reproductive health outcomes such as conception delay, placenta previa, placental abruption, premature rupture of membranes, and preterm birth (3). In men, ev- 
idence suggests that smoking causes erectile dysfunction (3). Infants born to smokers are at increased risk of being born low birth weight and of dying from sudden infant death syndrome (SIDS) (3), and infants and children exposed to secondhand smoke (SHS) are at increased risk for SIDS, respiratory infections, more frequent and severe asthma attacks, and ear infections (4).

A disproportionate share of the global tobacco burden falls on developing countries, where $84 \%$ of the 1.3 billion current smokers reside (5). Although smoking prevalence is decreasing in high-income countries, it is increasing in many low- and middle-income countries (LMICs). In addition, according to a survey conducted in 151 LMICs, smoking prevalence estimates among adolescent girls and boys were similar in $58 \%$ of the sites, suggesting that increases in smoking in girls may give rise to increased smoking prevalence in women (6). However, smoking prevalence among reproductive-age adults in many LMICs is not known (7). The most recent study reported smoking prevalence estimates in 14 Latin American countries during the 1980s and 1990s (8). More recent data are needed to describe the smoking patterns in adult men and women to inform tobacco control efforts and to assess the magnitude of potential health effects on maternal and child health.

Reproductive Health Surveys (RHS) are nationally representative surveys of households with women and men of reproductive age in selected LMICs, and include questions on tobacco use (9). Using RHS data, the current study estimated smoking prevalence by gender; described patterns of cigarette use; and identified predictors of current cigarette smoking in four Latin American countries (Ecuador, El Salvador, Guatemala, and Honduras).

\section{MATERIALS AND METHODS}

The current study analyzed RHS data for women in Ecuador (2004), El Salvador (2002-2003), Guatemala (2002), and Honduras (2001), and RHS data for men in El Salvador, Guatemala, and Honduras for the same years. These countries were selected because they had the most recent survey data, and were in one single World Health Organization (WHO) region (and thus were expected to have similar patterns of tobacco use). The RHS assess a broad range of topics that may vary according to country needs and interests. Topics include reproductive health history, fertility, contraceptive use and knowledge, infant health and mortality, use of maternal and child health services, nutrition status of children and their mothers, child schooling, gender-based violence, use of alcohol and tobacco, and knowledge and attitudes of human immunodeficiency virus and acquired immunodeficiency syndrome (HIV / AIDS). The RHS included in this analysis were conducted with technical assistance from the U.S. Centers for Disease Control and Prevention (CDC) through support and funding from the U.S. Agency for International Development (USAID).

Surveys were conducted separately for women of reproductive age (15-49 years) and men of reproductive age (15-59 years). Respondents were selected using a three-stage sampling strategy based on the political or administrative divisions of each country. For the first stage, census areas were randomly selected proportional to number of households. In the second stage, all households were enumerated and one household was randomly selected as a starting point for conducting the first of 30 household surveys. In the final stage, participants were randomly selected from listings of eligible household members. The women and men's surveys used separate sampling frames. Consequently, female and male respondents were not from the same households. Because institutions such as convents, prisons, military establishments, and hotels were excluded from the survey, the RHS data collected in the study were representative of the noninstitutionalized population in each country. The surveys were conducted by trained data collectors through face-to-face interviews in nationally relevant languages (most commonly Spanish). Female interviewers administered the women's surveys and male interviewers administered the men's surveys. Data were weighted to adjust for sampling design and non-responders so that the data set would be representative of households with women or men of reproductive age in each country. Response rates ranged from $91.2 \%$ (El Salvador) to $97.0 \%$ (Ecuador) for the women's surveys and from $79.4 \%$ (El Salvador) to $85.7 \%$ (Guatemala) for the men's surveys. De- tailed methods of the surveys are described elsewhere (10-13).

\section{Variables}

Self-reported smoking status was determined from respondents' reports of having ever smoked cigarettes and smoking in the last 30 days. Respondents were categorized as either "current" or non-current smokers. Current smokers were defined as those who reported smoking any number of cigarettes in the last 30 days and were subdivided into daily and non-daily smokers. Non-current smokers were divided into "never smokers" and "former smokers." Never smokers were defined as those who reported never having smoked cigarettes. Former smokers were defined as those who reported ever having smoked cigarettes but not in the last 30 days. Quit ratios were calculated by dividing the number of former smokers by the sum of current and former smokers (ever-smokers), multiplied by 100 . Respondents were not asked about use of other tobacco products (e.g., pipes, water pipes, smokeless tobacco, and bidis-small, hand-rolled cigarettes sold in a variety of flavors).

Variables assessed as potential risk factors for current smoking included age; residence (urban versus rural); education; marital status; socioeconomic status; and current pregnancy status (women's surveys only). Having children $<5$ years old was assessed as a crude measure of potential SHS exposure in young children. Female participants were divided into three age groups (15-24, 25-34, and 35-49 years old) and men were divided into four age groups (15-24, 25-34, 35-44, and 45-59 years old). Education was categorized as "no schooling," "1st-6th grade education," and "7th grade or higher education," based on the highest grade completed. Marital status was categorized as "currently married" (including commonlaw marriage); "previously married" (divorced, widowed, or separated); and "never married." Socioeconomic status was derived from a description of household assets and access to services and was classified as "low," "middle," or "high" (14). Whether respondents had children younger than 5 years old was determined from respondents' lists of biological children and their living arrangements. Current pregnancy status was self-reported 
during the interview. Women who did not know if they were pregnant were combined with women who reported that they were not pregnant.

\section{Analysis}

Data were analyzed by using SAS version 9.2 (SAS Institute Inc., Cary, NC, USA) and were weighted to be nationally representative. Women and men's surveys were analyzed separately by country and by gender, and prevalence of the different types of smoking status was calculated. For current smokers, intensity of smoking was classified as either non-daily or daily, and by number of cigarettes smoked per day. For daily smokers, the weighted median number of cigarettes smoked per day was calculated. Bivariate analysis was used to assess crude associations of current smoking and selected risk factors. Chi-square tests were used to examine differences at a significance level of 0.05 , and $95 \%$ confidence intervals (CIs) were constructed for all weighted point estimates. Using logistic regression, adjusted odds ratios (aORs) were calculated to identify independent associations between each risk factor and smoking, controlling for all other selected risk factors.

\section{RESULTS}

Current smoking prevalence in women ranged from $2.6 \%$ in Guatemala to $13.1 \%$ in Ecuador, and quit ratios ranged from $50.4 \%$ in Ecuador to $75.2 \%$ in Honduras (Table 1). Smoking prevalence in men ranged from $23.1 \%$ in Guatemala to $34.9 \%$ in El Salvador, and quit ratios ranged from $50.1 \%$ in El Salvador to $60.9 \%$ in Guatemala.

In both gender groups, non-daily smoking was common (Table 2). Nondaily smokers represented nearly half of current female smokers in El Salvador $(46.3 \%)$ and over two-thirds of current female smokers in Ecuador (67.6\%). In El Salvador, the country with the highest prevalence of male current smokers $(34.9 \%$ ) (Table 1$), 42.2 \%$ of current male smokers were non-daily smokers (Table 2 ). The median number of cigarettes smoked per day in female daily smokers ranged from 1.9 (Ecuador, Honduras) to 2.3 (Guatemala); male daily smokers reported smoking a median of 2.1 (Guatemala) to 3.6 (Honduras) cigarettes per day.

\section{Women of reproductive age (15-49 years)}

In the bivariate analysis, in all countries, higher smoking prevalence was significantly associated in women who lived in urban areas, were previously married, and/or had high socioeconomic status (Table 3). In Ecuador, Guatemala, and Honduras, higher smoking prevalence was significantly associated in women who were 35-49 years of age, had completed seven or more grades of school, and/or were not currently pregnant. In Ecuador, El Salvador, and Honduras, higher smoking prevalence was significantly associated in women who did not have children younger than 5 years old.

After controlling for all other characteristics, risk factors independently associated with current smoking in women varied by country (Table 3). In Ecuador, being previously married (aOR 1.4, 95\% CI 1.2-1.8) and having middle or high socioeconomic status (aOR 1.7, 95\% CI 1.5-2.1, and aOR 2.8, 95\% CI 2.2-3.5, respectively) were significantly associated with current smoking. However, being currently pregnant (aOR 0.3, 95\% CI $0.2-0.6)$ was inversely associated with current smoking. In El Salvador, urban residence (aOR 2.2, 95\% CI 1.6-3.1) and being previously married (aOR 1.7, 95\% CI 1.1-2.7) were significantly associated with current smoking; having children younger than 5 years old (aOR 0.6, 95\% CI 0.4-0.8) was inversely associated with current smoking. In Guatemala, being 35-49 years old (aOR 1.8, 95\% CI 1.1-3.1) and having seven or more years of schooling (aOR 2.2, 95\% CI 1.2-3.8) were significantly associated with current smoking; having middle socioeconomic status (aOR $0.5,95 \%$ CI $0.3-0.9$ ) and being currently pregnant (aOR $0.2,95 \%$ CI 0.1-0.5) were inversely associated with current smoking. In Honduras, urban residence (aOR 1.8, 95\% CI 1.3-

TABLE 1. Prevalence of never, former, and current smokers, and quit ratios, for women and men of reproductive age in Ecuador, El Salvador, Guatemala, and Honduras, 2001-2004

\begin{tabular}{|c|c|c|c|c|c|}
\hline Country (year) & $\begin{array}{l}\text { Never smoker } \\
\%\left(\left.C\right|^{b}\right)\end{array}$ & $\begin{array}{c}\text { Former smoker } \\
\%(\mathrm{Cl})\end{array}$ & $\begin{array}{c}\text { Current smoker } \\
\%(\mathrm{Cl})\end{array}$ & $\begin{array}{l}\text { Quit } \\
\text { ratioc }^{c}\end{array}$ & $n$ \\
\hline \multicolumn{6}{|l|}{ Ecuador (2004) } \\
\hline Men & $-^{d}$ & - & - & - & - \\
\hline \multicolumn{6}{|c|}{ El Salvador (2002-2003) } \\
\hline Women & $87.5(86.4-88.7)$ & $8.0(7.1-9.0)$ & $4.4(3.7-5.1)$ & 64.5 & 10689 \\
\hline \multicolumn{6}{|l|}{ Guatemala (2002) } \\
\hline Women & $90.2(89.1-91.3)$ & $7.2(6.2-8.2)$ & $2.6(2.1-3.2)$ & 73.5 & 9152 \\
\hline Men & $41.0(37.9-44.1)$ & $35.9(32.9-38.9)$ & $23.1(20.7-25.5)$ & 60.9 & 2537 \\
\hline \multicolumn{6}{|l|}{ Honduras (2001) } \\
\hline Women & 87.5 (86.7-88.3) & $9.4(8.7-10.1)$ & $3.1(2.6-3.5)$ & 75.2 & 8362 \\
\hline Men & $34.8(32.7-36.9)$ & $35.4(33.3-37.5)$ & $29.8(27.8-31.9)$ & 52.3 & 3247 \\
\hline
\end{tabular}


TABLE 2. Intensity of smoking in current smokers by country and sex: Ecuador, El Salvador, Guatemala, and Honduras, 2001-2004a

\begin{tabular}{|c|c|c|c|c|}
\hline \multirow[b]{2}{*}{ Country (year) } & \multirow{2}{*}{$\begin{array}{l}\text { Non-daily } \\
\text { smokers } \\
\%\left(\mathrm{Cl}^{\mathrm{b}}\right)\end{array}$} & \multicolumn{3}{|c|}{$\begin{array}{c}\text { Daily } \\
\text { smokers:c }^{c} \\
\text { Number of cigarettes per day }\end{array}$} \\
\hline & & $\begin{array}{c}1-2 \\
\%(\mathrm{Cl})\end{array}$ & $\begin{array}{c}3+ \\
\%(\mathrm{Cl})\end{array}$ & Median (Cl) \\
\hline \multicolumn{5}{|l|}{ Ecuador (2004) } \\
\hline Women $(n=1255)$ & $67.6(64.4-70.7)$ & $16.8(14.3-19.3)$ & $15.6(13.1-18.1)$ & $1.9(1.8-2.0)$ \\
\hline Men & $-^{d}$ & - & - & - \\
\hline \multicolumn{5}{|l|}{ El Salvador (2002-2003) } \\
\hline Women $(n=400)$ & $46.3(38.3-54.3)$ & $27.1(20.2-34.0)$ & $26.6(20.4-32.8)$ & $2.0(1.9-2.1)$ \\
\hline Men $(n=486)$ & $42.2(36.8-47.7)$ & $22.4(17.6-27.1)$ & $35.4(30.3-40.5)$ & $3.0(2.5-3.4)$ \\
\hline \multicolumn{5}{|l|}{ Guatemala (2002) } \\
\hline Women $(n=165)$ & $19.9(11.2-28.5)$ & $35.3(25.3-45.2)$ & $44.9(33.6-56.2)$ & $2.3(1.7-2.8)$ \\
\hline $\operatorname{Men}(n=600)$ & $22.8(18.3-27.2)$ & $37.5(31.5-43.5)$ & $39.7(34.0-45.4)$ & $2.1(1.7-2.4)$ \\
\hline \multicolumn{5}{|l|}{ Honduras (2001) } \\
\hline Women $(n=257)$ & $28.3(21.9-34.6)$ & $36.7(30.0-43.3)$ & $35.0(28.4-41.7)$ & $1.9(1.8-2.1)$ \\
\hline $\operatorname{Men}(n=1001)$ & $19.4(15.8-23.0)$ & $28.4(24.7-32.1)$ & $52.2(48.1-56.3)$ & $3.6(3.1-4.2)$ \\
\hline
\end{tabular}

TABLE 3. Prevalence and adjusted odds ratios (aORs) ${ }^{a}$ of current smoking in women of reproductive age by selected characteristics: Ecuador, El Salvador, Guatemala, and Honduras, 2001-2004

\begin{tabular}{|c|c|c|c|c|c|c|c|c|}
\hline \multirow[b]{2}{*}{ Characteristic } & \multicolumn{2}{|c|}{$\begin{array}{c}\text { Ecuador } \\
(n=10814)\end{array}$} & \multicolumn{2}{|c|}{$\begin{array}{l}\text { El Salvador } \\
(n=10689)\end{array}$} & \multicolumn{2}{|c|}{$\begin{array}{l}\text { Guatemala } \\
(n=9152)\end{array}$} & \multicolumn{2}{|c|}{$\begin{array}{l}\text { Honduras } \\
(n=8362)\end{array}$} \\
\hline & $\%$ & $\mathrm{aOR}\left(\mathrm{Cl}^{\mathrm{C}}\right)$ & $\%$ & $\mathrm{aOR}(\mathrm{Cl})$ & $\%$ & $\mathrm{aOR}(\mathrm{Cl})$ & $\%$ & $\mathrm{aOR}(\mathrm{Cl})$ \\
\hline \multicolumn{9}{|l|}{ Age (years) ${ }^{d, e, f}$} \\
\hline $15-24$ & 12.1 & Ref $g$ & 3.6 & Ref & 1.7 & Ref & 2.6 & Ref \\
\hline $25-34$ & 12.7 & $1.1(0.9-1.3)$ & 4.3 & $1.0(0.7-1.5)$ & 2.3 & $1.2(0.7-2.1)$ & 2.5 & $0.9(0.6-1.4)$ \\
\hline $35-49$ & 14.5 & $1.1(0.9-1.4)$ & 5.6 & $1.0(0.7-1.6)$ & 4.2 & $1.8(1.1-3.1)^{i}$ & 4.3 & $1.4(0.9-2.1)$ \\
\hline \multicolumn{9}{|l|}{ Area of residence ${ }^{\mathrm{d}, \mathrm{e}, \mathrm{f}, \mathrm{h}}$} \\
\hline Rural & 8.4 & Ref & 2.6 & Ref & 1.6 & Ref & 1.7 & Ref \\
\hline Urban & 16.2 & $1.2(1.0-1.5)$ & 5.8 & $2.2(1.6-3.1)^{i}$ & 4.0 & $1.5(0.8-2.6)$ & 4.4 & $1.8(1.3-2.6)^{i}$ \\
\hline \multicolumn{9}{|c|}{ Education (highest grade completed) ${ }^{\mathrm{d}, \mathrm{e}, \mathrm{f}}$} \\
\hline None & 6.7 & Ref & 5.6 & Ref & 1.5 & Ref & 3.4 & Ref \\
\hline $1-6$ & 9.3 & $1.3(0.8-2.8)$ & 3.5 & $0.6(0.4-1.0)$ & 1.7 & $1.0(0.6-1.7)$ & 2.0 & $0.5(0.3-0.8)^{i}$ \\
\hline$\geq 7$ & 15.8 & $1.6(0.9-2.7)$ & 4.8 & $0.7(0.4-1.3)$ & 4.9 & $2.2(1.2-3.8)^{i}$ & 5.0 & $0.9(0.5-1.4)$ \\
\hline \multicolumn{9}{|l|}{ Marital status $\mathrm{s}^{\mathrm{d}, \mathrm{e}, \mathrm{f}, \mathrm{h}}$} \\
\hline Married & 12.1 & Ref & 4.1 & Ref & 2.6 & Ref & 2.7 & Ref \\
\hline Previously married & 17.5 & $1.4(1.2-1.8)^{i}$ & 8.0 & $1.7(1.1-2.7)^{\mathrm{i}}$ & 5.6 & $1.8(0.9-3.4)$ & 4.7 & $1.5(1.1-2.2)^{i}$ \\
\hline Never married & 13.7 & $1.0(0.8-1.3)$ & 3.6 & $0.7(0.5-1.1)$ & 1.9 & $0.6(0.3-1.2)$ & 3.0 & $0.9(0.5-1.4)$ \\
\hline \multicolumn{9}{|l|}{ Socioeconomic status ${ }^{\mathrm{d}, \mathrm{e}, \mathrm{ft}, \mathrm{h}}$} \\
\hline Low & 6.4 & Ref & 3.1 & Ref & 1.4 & Ref & 1.8 & Ref \\
\hline Middle & 12.3 & $1.7(1.5-2.1)^{\mathrm{i}}$ & 4.7 & $1.1(0.7-1.5)$ & 0.9 & $0.5(0.3-0.9)^{i}$ & 2.3 & $0.9(0.6-1.4)$ \\
\hline High & 19.9 & $2.8(2.2-3.5)^{i}$ & 5.4 & $1.0(0.7-1.6)$ & 4.6 & $1.6(0.8-3.1)$ & 5.6 & $1.7(1.0-2.7)$ \\
\hline \multicolumn{9}{|l|}{ Currently pregnant ${ }^{d, e, f}$} \\
\hline No/don't know & 13.5 & Ref & 4.5 & Ref & 2.8 & Ref & 3.2 & Ref \\
\hline Yes & 4.3 & $0.3(0.2-0.6)^{i}$ & 3.7 & $0.9(0.2-4.2)$ & 0.4 & $0.2(0.1-0.5)^{i}$ & 1.9 & $0.8(0.4-1.5)$ \\
\hline \multicolumn{9}{|l|}{ Have child $<5$ years old d,f,h } \\
\hline No & 14.2 & Ref & 5.1 & Ref & 3.0 & Ref & 3.6 & Ref \\
\hline Yes & 10.7 & $0.9(0.7-1.0)$ & 2.8 & $0.6(0.4-0.8)^{i}$ & 2.0 & $0.9(0.5-1.6)$ & 2.2 & $0.8(0.6-1.1)$ \\
\hline
\end{tabular}

adjusted for age, residence, education, having a child $<5$ years old, marital status, socioeconomic status, and pregnancy status (versus non-smokers).

b Based on data from Reproductive Health Surveys. Data were weighted to be nationally representative of households with reproductive-age women. Unweighted sample numbers are provided.

${ }^{c} \mathrm{Cl}: 95 \%$ confidence interval.

${ }^{d}$ Chi-square test $(P<0.05$ for women in Ecuador).

e Chi-square test $(P<0.05$ for women in Guatemala).

${ }^{f}$ Chi-square test $(P<0.05$ for women in Honduras).

9 Ref: reference group.

h Chi-square test $(P<0.05$ for women in El Salvador).

i $P<0.05$. 
TABLE 4. Prevalence and adjusted odds ratios (aORs) of current smoking in men of reproductive age by selected characteristics: El Salvador, Guatemala, and Honduras, 2001-2003 ${ }^{b}$

\begin{tabular}{|c|c|c|c|c|c|c|}
\hline \multirow[b]{2}{*}{ Characteristic } & \multicolumn{2}{|c|}{$\begin{array}{l}\text { El Salvador } \\
(n=1315)\end{array}$} & \multicolumn{2}{|c|}{$\begin{array}{l}\text { Guatemala } \\
(n=2537)\end{array}$} & \multicolumn{2}{|c|}{$\begin{array}{l}\text { Honduras } \\
(n=3247)\end{array}$} \\
\hline & $\%$ & $\mathrm{aOR}\left(\mathrm{Cl}^{\mathrm{c}}\right)$ & $\%$ & $\mathrm{aOR}(\mathrm{Cl})$ & $\%$ & $\mathrm{aOR}(\mathrm{Cl})$ \\
\hline \multicolumn{7}{|l|}{ Age (years) $^{\mathrm{h}}$} \\
\hline $15-24$ & 36.8 & $\operatorname{Ref}^{d}$ & 21.3 & Ref & 30.0 & Ref \\
\hline $25-34$ & 38.8 & $0.9(0.6-1.5)$ & 25.6 & $1.0(0.6-1.5)$ & 33.5 & $1.1(0.8-1.5)$ \\
\hline \multicolumn{7}{|l|}{ Area of residence ${ }^{h}$} \\
\hline Rural & 31.5 & Ref & 22.3 & Ref & 28.9 & Ref \\
\hline Urban & 38.4 & $1.4(1.0-2.0)$ & 24.2 & $1.2(0.8-1.7)$ & 30.9 & $1.4(1.1-1.7)^{\mathrm{e}}$ \\
\hline \multicolumn{7}{|c|}{ Education (highest grade completed) ${ }^{\dagger}$} \\
\hline None & 29.4 & Ref & 26.9 & Ref & 28.9 & Ref \\
\hline Previously married & 35.2 & $0.8(0.5-1.3)$ & 40.0 & $2.4(1.4-4.4)^{\mathrm{e}}$ & 36.4 & $1.2(0.8-1.8)$ \\
\hline Never married & 39.4 & $1.2(0.7-2.1)$ & 20.1 & $1.0(0.6-1.5)$ & 29.3 & $0.9(0.6-1.2)$ \\
\hline \multicolumn{7}{|l|}{ Socioeconomic status } \\
\hline Low & 34.7 & Ref & 25.4 & Ref & 30.7 & Ref \\
\hline Middle & 33.8 & $0.8(0.6-1.2)$ & 20.7 & $0.8(0.6-1.1)$ & 30.8 & $0.9(0.7-1.2)$ \\
\hline High & 36.4 & $0.9(0.6-1.4)$ & 23.6 & $1.1(0.7-1.8)$ & 26.3 & $0.8(0.6-1.2)$ \\
\hline \multicolumn{7}{|l|}{ Have child $<5$ years oldg } \\
\hline No & 34.4 & Ref & 21.4 & Ref & 30.3 & Ref \\
\hline Yes & 36.7 & $1.0(0.6-1.5)$ & 27.4 & $1.5(1.1-2.1)^{\mathrm{e}}$ & 28.2 & $0.8(0.6-1.0)$ \\
\hline
\end{tabular}

2.6) and being previously married (aOR $1.5,95 \%$ CI 1.1-2.2) were significantly associated with current smoking; having $1-6$ years of schooling (aOR 0.5, 95\% CI 0.3-0.8) was inversely associated with current smoking.

\section{Men of reproductive age (15-59 years)}

In the bivariate analysis, characteristics associated with current smoking in men varied by country (Table 4 ). In El Salvador, lower smoking prevalence was significantly associated in men who were 45-59 years of age or lived in rural residences. In Guatemala, higher smoking prevalence was significantly associated in men who were previously married and had children younger than 5 years old. In Honduras, higher smoking prevalence was significantly associated in men with a 1st-6th grade education.

After controlling for all other characteristics, risk factors independently associated with current smoking in men varied by country. In El Salvador, being
45-59 years of age (aOR 0.5, 95\% CI 0.30.8 ) was inversely associated with current smoking (Table 4). In Guatemala, being previously married (aOR 2.4, 95\% CI 1.4-4.4) and having children younger than 5 years old (aOR 1.5, 95\% CI 1.1-2.1) were associated with current smoking. In Honduras, being 45-59 years of age (aOR $0.7,95 \%$ CI $0.5-0.9)$ was inversely associated with current smoking, and urban residence (aOR 1.4, 95\% CI 1.1-1.7) was associated with current smoking.

\section{DISCUSSION}

The results of this study provide up-todate, nationally representative estimates of current smoking prevalence in reproductive-age adults in four Latin American countries. Substantial disparities were found by gender (smoking was 7.9-9.6 times more prevalent among men than women, depending on the country). Moreover, in each country surveyed, at least one-fifth of men of reproductive age reported smoking daily, and male daily smokers reported a greater number of cigarettes smoked per day than female daily smokers. A pattern of higher tobacco use in men versus women is consistent with patterns reported in an earlier study that examined smoking prevalence in the general adult population in 14 Latin American countries (8). In that analysis, the authors concluded the majority of countries studied were in Stage 2 of the tobacco epidemic model proposed by Lopez et al. (15): high prevalence and rising incidence among men, and low prevalence and slightly increasing incidence among women. While not directly comparable, as the earlier study based prevalence estimations on adults of all ages, both studies suggest cessation programs carried out as part of coordinated tobacco control programs should focus on the male population to decrease overall smoking prevalence in the Latin American region $(2,16)$.

In the past, smoking in Latin American countries was largely confined to males. However, by the late 20th century, both men and women were smoking (17). Re- 
cent data for youth in LMICs suggest tobacco use is becoming increasingly acceptable among females (6). The current study showed low smoking prevalence in women for all countries except Ecuador, but indicated higher risk (for all countries) for women who had high socioeconomic status, lived in urban areas, and/or were previously married. These findings suggest acceptability of smoking may be increasing among subgroups of women, which is consistent with evidence that changes in culture and traditions as well as greater economic freedom among women may give rise to increased smoking (18). Further evidence of these changes can be seen in a study of 74 countries by Hitchman et al., which showed a positive association between a country's measure of women's empowerment (e.g., economic and political participation/decision-making and power over economic resources) and national smoking rates in women relative to men (19). Thus, countries where smoking among women is low and women are becoming increasingly empowered should pay particular attention to tobacco control to prevent increases in women's smoking. The tobacco industry's aggressive marketing of tobacco products to young women in Latin America, including the promotion of the association of smoking with Western ideals of independence, sophistication, wealth, and sex appeal $(18,20)$, is another factor that should be considered, and its effect on women's tobacco use in this region further explored. One issue of particular concern is that increased smoking prevalence in nonpregnant women may give rise to a higher proportion of women who enter pregnancy smoking, which could undermine recent gains in maternal and child health in LMICs. In recognition of the harm of tobacco exposure to women and children, the United Nations passed a resolution in 2010 encouraging member states to implement tobacco control programs to protect children and pregnant women's health (21).

SHS exposure in women and children is common in LMICs. WHO estimates that $40 \%$ of children worldwide (about 700 million) are exposed to SHS in the home (2). Of all deaths attributable to SHS globally, 31\% occurred among children and $64 \%$ were among women (2). Given the high prevalence of smoking in men in the current study $(23.1 \%-34.9 \%)$, and the fact that one-third of male smok- ers reported having one or more children younger than 5 years old in their household, reducing SHS exposure should be a public health priority. Investments into comprehensive tobacco control programs are needed to help parents, caregivers, and families quit smoking and eliminate tobacco exposure in the home. In a Cochrane review of 36 studies examining interventions to reduce parental smoking and children's exposure, the authors concluded that while there was insufficient evidence to support a single strategy, intensive counseling provided in clinical settings may be promising (22). However, population-based strategies, such as public education campaigns on the health effects of SHS, and smoke-free air laws, which have been shown to affect social norms of smoking around non-smokers, may be more costeffective in reducing SHS exposure than individually based programs targeted to parents (23). Further study of interventions to reduce SHS exposure in infants and children is needed in Latin American countries.

Previous research indicated a per capita cigarette consumption of 234 to 450 cigarettes per year across the four countries in the current study-a relatively low range compared to Argentina, which has the highest per capita consumption in the region at 1014 cigarettes per year (24). In the current study, a substantial proportion of current smokers reported that they did not smoke every day, and daily smokers reported smoking few cigarettes per day. These findings are consistent with data indicating that lighter smokers may represent a higher proportion of total smokers in LMICs versus high-income countries $(25,26)$. This may be a result of local marketing practices. For example, in Latin America and the Caribbean, cigarettes are often sold in packs of 10 instead of the traditional 20-per-pack (20), and individually (27), to make smoking more affordable. Nevertheless, studies have found that non-daily smokers, like daily smokers, are at increased risk for respiratory symptoms and cardiovascular mortality compared with non-smokers (28-30). More research is needed to better understand smoking and addiction patterns in non-daily smokers, and intervention strategies are needed to promote cessation in non-daily smokers before they progress to daily smoking and higher levels of addiction.
The WHO Framework Convention on Tobacco Control (FCTC) was developed in response to the globalization of the tobacco epidemic and the need for control strategies (31). In a February 2008 report (1), WHO outlined the MPOWER package, a set of six measures to support country-level implementation of policies to reduce the demand for tobacco. These measures included: 1) monitoring tobacco use and prevention policies; 2) protecting people from tobacco smoke; 3) offering help to those who want to quit tobacco use; 4) warning about dangers of tobacco; 5) enforcing bans on tobacco advertising, promotion, and sponsorship; and 6) raising taxes on tobacco (2). As of 2008, all four countries included in the current study had made progress toward implementing some of these steps, but additional measures are needed (2). For example, all four countries have excise taxes on cigarettes of at least $31 \%$ of the retail price of cigarettes (2), but none have implemented pictorial health warnings (which have proven effective in populations with low literacy), and only Guatemala and Honduras have passed comprehensive smoking bans $(2,32)$. Data from future RHS could be used to help monitor tobacco use-an important component of the MPOWER recommendations. In addition, all or a selected number of questions from a standardized set of tobacco questions, developed by $\mathrm{CDC}, \mathrm{WHO}$, and international partners, could be implemented by countries to obtain reliable and comparable estimates in monitoring tobacco use and exposure (33). Countries could also use the findings of the current study to inform national tobacco control programs.

This study had several limitations. First, smoking status and number of cigarettes smoked per day were based on self-report, and studies conducted in high-income countries with biochemical validation show that self-reported smoking status underestimates true prevalence of smoking (34). Non-disclosure rates in the four participating countries are unknown. Second, the RHS only asked about cigarette smoking, so use of other tobacco products was not obtained. Third, the authors were not able to assess smoking status for all household members, precluding measurement of total SHS exposure. Finally, the research and analysis was limited to the four countries that had available RHS data during the selected study period. 
In summary, the current analysis found a high prevalence of smoking in men, a relatively low prevalence of smoking in women, and the potential for high prevalence of SHS exposure for young children living in households with adults of reproductive age. Nondaily smokers and light daily smokers (those who smoked only a few cigarettes per day) were common. More research is needed to better understand addiction patterns in these smokers and to identify the most effective interventions. National tobacco control efforts should continue to implement the WHO MPOWER measures to help current smokers quit and to prevent non-smokers from starting tobacco use so that smoking rates remain low in women and are reduced in men. More work is also needed to identify effective strategies for preventing and decreasing SHS exposure in the home, especially among vulnerable women and children.
Acknowledgments. The authors would like to acknowledge Alicia Ruiz, Paul Stupp, and Stephen McCracken for their expertise on the Reproductive Health Surveys.

Disclaimer. The findings and conclusions found in this report are those of the authors and do not necessarily represent the official position of the U.S. Centers for Disease Control and Prevention.

\section{REFERENCES}

1. World Health Organization. WHO report on the global tobacco epidemic, 2008: the MPOWER package. Geneva: WHO; 2008.

2. World Health Organization. WHO report on the global tobacco epidemic, 2009: implementing smoke-free environments. Geneva: WHO; 2009.

3. U.S. Department of Health and Human Services. The health consequences of smoking: a report of the Surgeon General. Atlanta: U.S. DHHS, Centers for Disease Control and Prevention, National Center for Chronic Disease Prevention and Health Promotion, Office on Smoking and Health; 2004.

4. U.S. Department of Health and Human Services. The health consequences of involuntary exposure to tobacco smoke: a report of the Surgeon General. Atlanta: U.S. DHHS, Centers for Disease Control and Prevention, Coordinating Center for Health Promotion, National Center for Chronic Disease Prevention and Health Promotion, Office on Smoking and Health; 2006.

5. Jha P, Chaloupka FJ. The economics of global tobacco control. BMJ. 2000;321(7257):358-61.

6. Warren CW, Jones NR, Peruga A, Chauvin J, Baptiste JP, Costa de Silva V, et al. Global youth tobacco surveillance, 2000-2007. MMWR Surveill Summ. 2008;57(1):1-28.

7. Bloch M, Tong VT, Novotny TE, England LJ, Dietz PM, Kim SY, et al. Tobacco use and secondhand smoke exposure among pregnant women in low- and middle-income countries: a call to action. Acta Obstet Gynecol Scand. 2010;89(4):418-22.

8. da Costa e Silva VL, Koifman S. Smoking in Latin America: a major public health problem. Cad Saude Publica. 1998;14 Suppl 3:99-108.

9. Centers for Disease Control and Prevention (US). International Reproductive Health Surveys [homepage on the Internet]. Atlanta: CDC; c2009. Available from: http://www. cdc.gov/reproductivehealth/surveys/ Accessed 13 October 2010.

10. Centro de Estudios de Población y Desarrollo Social (EC); Centers for Disease Control and Prevention (US). Encuesta Demográfica y de Salud Materna e Infantil: ENDEMAIN 2004 [Internet]. Quito: CEPDS; 2005. Available from: http://www.cepar.org.ec/endemain_ 04/nuevo05/indice.htm Accessed 16 January 2010.

11. Asociación Hondureña de Planificación de Familia (HN); Centers for Disease Control and Prevention (US). Encuesta Nacional de Epidemiologia y Salud Familiar: ENESF-2001. Encuesta Nacional de Salud Masculina: ENSM-2001 [Internet]. Tegucigalpa: AHPF; 2002. Available from: http://pdf.usaid.gov/ pdf_docs/PNACQ675.pdf Accessed 16 January 2010.

12. Asociación Demográfica Salvadoreña (SV); Centers for Disease Control and Prevention (US). Encuesta Nacional de Salud Familiar: FESAL 2002/03. Informe Final [Internet]. San Salvador: ADS; 2004. Available from: http:// www.fesal.org.sv/2003/informe/final/ Default.htm Accessed 16 January 2010.

13. Instituto Nacional de Estadística (GT); Centro de Estudios en Salud de Centro America y Panamá, Universidad del Valle de Guatemala; Centers for Disease Control and Prevention (US). Encuesta Nacional de Salud Materno Infantil 2002. Ciudad de Guatemala: INE; 2003.

14. Rutstein S, Johnson K. The DHS wealth index. DHS Comparative Reports No. 6. Calverton, MD: ORC Macro; 2004.

15. Lopez AD, Collishaw NE, Piha T. A descriptive model of the cigarette epidemic in developed countries. Tob Control. 1994;3(3):242-7.

16. Mackay JL. The fight against tobacco in developing countries. Tuber Lung Dis. 1994;75(1): 8-24.

17. Waldron I, Bratelli G, Carriker L, Sung WC, Vogeli C, Waldman E. Gender differences in tobacco use in Africa, Asia, the Pacific, and Latin America. Soc Sci Med. 1988;27(11):1269-75.

18. Nichter M, Greaves L, Bloch M, Paglia M, Scarinci I, Tolosa JE, et al. Tobacco use and secondhand smoke exposure during pregnancy in low- and middle-income countries: the need for social and cultural research. Acta Obstet Gynecol Scand. 2010;89(4):465-77.

19. Hitchman SC, Fong GT. Gender empowerment and female-to-male smoking prevalence ratios. Bull World Health Organ. 2011;89(3): 195-202.

20. Aguinaga Bialous S, Shatenstein S. Profits over people: tobacco industry activities to market cigarettes and undermine public health in Latin America and the Caribbean. Washington: Pan American Health Organization; 2002.

21. United Nations Economic and Social Council. Tobacco use and maternal and child health, Resolution 2010/8 [Internet]. 22 July 2010. New York, ECOSOC, 2010. Available from: www.un.org/en/ecosoc/docs/2010/res\% 202010-8.pdf Accessed 21 April 2011.

22. Priest N, Roseby R, Waters E, Polnay A, Campbell R, Spencer N, et al. Family and carer smoking control programmes for reducing children's exposure to environmental tobacco smoke. Cochrane Database Syst Rev. 2008;(4):CD001746.

23. International Agency for Research on Cancer. IARC handbooks of cancer prevention: tobacco control. Volume 13. Evaluating the effectiveness of smoke-free policies [Internet]. Lyon, France: IARC; 2009. Available from: http://www.iarc.fr/en/publications/pdfsonline/prev/handbook13/handbook13.pdf Accessed 20 June 2011.

24. Shafey O, Eriksen M, Ross H, Mackay J. The Tobacco Atlas [Internet]. 3rd ed. Atlanta: American Cancer Society; 2009. Available from: www.tobaccoatlas.org/ Accessed 20 April 2011.

25. Fagan P, Rigotti NA. Light and intermittent smoking: the road less traveled. Nicotine Tob Res. 2009;11(2):107-10.

26. National Cancer Institute (US). What's in a name? Examination of light and intermittent smokers: helping to set a tobacco control research agenda. Executive summary. Washington: NCI; 2007

27. Ockene JK, Chiriboga DE, Zevallos JC. Smoking in Ecuador: prevalence, knowledge, and attitudes. Tob Control. 1996;5(2):121-6.

28. An LC, Berg CJ, Klatt CM, Perry CL, Thomas JL, Luo X, et al. Symptoms of cough and shortness of breath among occasional young adult smokers. Nicotine Tob Res. 2009;11(2): $126-33$.

29. Luoto R, Uutela A, Puska P. Occasional smoking increases total and cardiovascular mortality among men. Nicotine Tob Res. 2000;2(2): 133-9.

30. Stoner L, Sabatier MJ, Black CD, McCully KK. Occasional cigarette smoking chronically af- 
fects arterial function. Ultrasound Med Biol. 2008;34(12):1885-92.

31. WHO Framework Convention on Tobacco Control [homepage on the Internet]. Geneva: World Health Organization; c2011. Available from: http://www.who.int/fctc/en/ Accessed 9 February 2011.

32. Cuevas F. Smoking ban in Honduras takes it to the next level. Huffington Post [Internet]. 2011 Feb 21; Health. Available from: http:// www.huffington post.com/2011/02/22/ smoking-ban-in-honduras-_n_826490.html Accessed 19 April 2011.

33. Global Tobacco Surveillance System (GTSS). Tobacco questions for surveys: a subset of key questions from the Global Adult Tobacco Survey (GATS). 2nd ed. Atlanta: Centers for Disease Control and Prevention; 2011. Available from: http://www.who.int/tobacco/ surveillance/tqs/en/index.html

34. Gorber SC, Schofield-Hurwitz S, Hardt J, Levasseur G, Tremblay M. The accuracy of self-reported smoking: a systematic review of the relationship between self-reported and cotinine-assessed smoking status. Nicotine Tob Res. 2009;11(1):12-24.

Manuscript received on 9 February 2011. Revised version accepted for publication on 13 May 2011

RESUMEN Objetivo. Calcular la prevalencia del tabaquismo según el sexo, describir los patrones de consumo de cigarrillos y determinar los factores predictivos del tabaquismo actual en mujeres y hombres en edad fértil en cuatro países latinoamericanos.

Patrones y factores predictivos del tabaquismo actual en mujeres y hombres en edad fértil en Ecuador, El Salvador, Guatemala y Honduras

Palabras clave
Métodos. Se analizaron los datos sobre tabaquismo proporcionados por los participantes de las Encuestas de Salud Reproductiva efectuadas en mujeres de 15 a 49 años de edad en Ecuador (2004), El Salvador (2002-2003), Guatemala (2002) y Honduras (2001), y en hombres de 15 a 59 años en El Salvador, Guatemala y Honduras en los mismos años. Se evaluó el tabaquismo actual según las características demográficas y se examinaron las asociaciones independientes mediante regresión logística. Se ponderaron los datos a fin de que fuesen representativos de hogares con mujeres y hombres en edad fértil a escala nacional.

Resultados. La prevalencia del tabaquismo actual varió entre 2,6\% (Guatemala) y $13,1 \%$ (Ecuador) en las mujeres y entre 23,1\% (Guatemala) y 34,9\% (El Salvador) en los hombres. En Ecuador, 67,6\% de las mujeres eran fumadoras ocasionales; en otros países, el consumo diario fue más prevalente que el ocasional tanto en los hombres como en las mujeres. En los consumidores diarios, la mediana del número de cigarrillos fumados por día varió entre 1,9 (Ecuador y Honduras) y 2,3 (Guatemala) en las mujeres y entre 2,1 (Guatemala) y 3,6 (Honduras) en los hombres. En el análisis bivariado, la prevalencia del tabaquismo en todos los países fue más alta en las mujeres que vivían en zonas urbanas, habían estado casadas o tenían un nivel socioeconómico alto. Los factores de riesgo de tabaquismo variaron según el país y el sexo.

Conclusiones. Los programas nacionales de control del tabaquismo de estos países deben orientarse principalmente a los habitantes de alto riesgo (hombres en edad fértil) y a mantener una prevalencia baja en los habitantes de bajo riesgo (mujeres en edad fértil). Se requieren más investigaciones para comprender los patrones de adicción de los fumadores ocasionales.

Tabaquismo; mujeres; hombres; salud sexual y reproductiva; embarazo; Ecuador; El Salvador; Guatemala; Honduras. 